\title{
GASPÉITE AND ASSOCIATED Ni-RICH MINERALS FROM VEINS IN ALTERED ULTRABASIC ROCKS FROM DUBOŠTICA, BOSNIA AND HERZEGOVINA
}

\author{
VLADIMIR BERMANEC ${ }^{\S}$ \\ Mineraloško-petrografski zavod, Geološki odsjek, PMF, Horvatovac bb, HR-10000 Zagreb, Croatia \\ GALIBA SIJARIĆ \\ Prirodno-matematički fakultet, Zmaja od Bosne 33, 71000 Sarajevo, Bosnia and Herzegovina \\ GORAN KNIEWALD \\ Department of Marine and Environmental Research, Rudjer Boskovic Institute, POB 180, HR-10002 Zagreb, Croatia \\ JOSEPH A. MANDARINO \\ Department of Earth Sciences, Royal Ontario Museum, 100 Queen's Park, Toronto, Ontario M5S 2C6, Canada

\begin{abstract}
A suite of nickel minerals, gaspéite, retgersite and nickelhexahydrite, was found in veins of altered ultramafic rocks from Duboštica, Bosnia and Hercegovina, in material deposited in the National Museum in Sarajevo. Unit-cell dimensions and volumes of the minerals are: gaspéite: $a$ 4.648(3), $c$ 14.95(2) $\AA$ (rhombohedral cell $a 5.660 \AA, \alpha 48.49^{\circ}$ ), $V 279.7 \AA^{3}$; retgersite: $a$ 6.787(5), $c$ 18.27(2) $\AA, V$ 842(1) $\AA^{3}$; nickelhexahydrite: $a$ 9.925(7), $b$ 7.232(7), c 24.16(2), $\beta$ 98.55(7),$V 1715(2) \AA^{3}$. The chemical composition of the gaspéite from Duboštica, obtained by ICP-AES analysis, is: $\mathrm{NiO} 49.63, \mathrm{MgO} 0.17, \mathrm{CaO} 0.45, \mathrm{FeO}$ $6.36, \mathrm{CO}_{2} 43.25$, total $99.87 \mathrm{wt} \%$. This gives the empirical formula (based on three atoms of oxygen) $\left(\mathrm{Ni}_{0.73} \mathrm{Fe}_{0.10} \mathrm{Ca}_{0.01}\right)_{\Sigma 0.84}$ $\mathrm{C}_{1.08} \mathrm{O}_{3.00}$. The association of gaspéite, retgersite and nickelhexahydrite has formed as a result of reactions involving a series of kinetically controlled transitory equilibria, and is characteristic of near-surface hydrothermal alteration.
\end{abstract}

Keywords: gaspéite, nickelhexahydrite, retgersite, ophiolite, Duboštica, Bosnia and Herzegovina.

\section{SOMMAIRE}

Nous documentons une association de minéraux de nickel, gaspéite, retgersite et nickelhexahydrite, occupant des veines dans des échantillons de roche ultramafique altérée provenant de Duboštica, Bosnie et Herzegovine, ceux-ci conservés dans la collection du Musée National à Sarajevo. Les dimensions de la maille élémentaire de ces minéraux ont été déterminées: gaspéite: $a$ 4.648(3), c 14.95(2) ̊ (maille rhomboédrique $\left.a 5.660 \AA, \alpha 48.49^{\circ}\right), V 279.7 \AA^{3}$; retgersite: $a 6.787(5), c 18.27(2) \AA, V 842(1) \AA^{3}$; nickelhexahydrite: $a$ 9.925(7), $b$ 7.232(7), $c$ 24.16(2), $\beta$ 98.55(7) ${ }^{\circ}, V 1715(2) \AA^{3}$. La composition chimique de la gaspéite de Duboštica, établie par analyse ICP-AES, serait: $\mathrm{NiO} 49.63, \mathrm{MgO} 0.17, \mathrm{CaO} 0.45, \mathrm{FeO} 6.36, \mathrm{CO}_{2} 43.25$, total 99.87\% (base pondérale). La formule empirique est calculée sur une base de trois atomes d'oxygène: $\left(\mathrm{Ni}_{0.73} \mathrm{Fe}_{0.10} \mathrm{Ca}_{0.01}\right)_{\Sigma 0.84} \mathrm{C}_{1.08} \mathrm{O}_{3.00}$. L'association de gaspéite, retgersite et nickelhexahydrite résulte de réactions impliquant une série d'équilibres transitoires régis cinétiquement, et serait caratéristique d'un phénomène d'altération hydrothermale près de la surface.

(Traduit par la Rédaction)

Mots-clés: gaspéite, nickelhexahydrite, retgersite, ophiolite, Duboštica, Bosnie et Herzegovine.

\$ E-mail address: vberman@public.srce.hr 


\section{INTRODUCTION}

Gaspéite is a rare Ni carbonate with a calcite-type structure. It was first described from the Gaspé Peninsula in Quebec, Canada (Kohls \& Rodda 1966), and later found in the Kambalda nickel mine, Western Australia and in the Native Pafuri Trust of northeastern Transvaal, Republic of South Africa (Mariano et al. 1969). It has now been found in ophiolites near Duboštica, Bosnia and Herzegovina.

Samples were collected by the Austrian geologist Katzer at the beginning of the century and saved in the collection of the National Museum in Sarajevo under inventory number 660-1920. The specimen with gaspéite, retgersite and nickelhexahydrite was recovered from a vein in an altered ultrabasic rock series near Duboštica. However, the precise location of the find is not mentioned in the documents of the museum.

This paper describes this new occurrence of gaspéite and its association with other rare nickel-rich minerals. A full description of the gaspéite is presented to supplement previous partial descriptions.

\section{Geological Setting}

The Duboštica occurrence of gaspéite and associated nickel-rich minerals is located $c a .10 \mathrm{~km}$ north of the town of Vares, in the central part of Bosnia and Herzegovina (Fig. 1). Numerous small deposits of chromian spinel occur in the broader area of Duboštica. Five active pits produced chromian spinel in the period from 1880 to 1941, but mining ceased after World War II. The geological setting of Duboštica is defined by the large Krivaja - Konjuh ultramafic massif, which covers an area of approximately 1000 square kilometers, and which is part of the Dinaric Ophiolite Zone. The massif itself is surrounded by a volcanic-sedimentary series of Jurassic age (the "Diabase - Chert Formation"), and there is a distinct tectonic character to the contact of these two units. The ultrabasic rock series consists mainly of nodular serpentinized as well as stratified lherzolites, enstatite dunites, pyroxenites and serpentinites. The chromian spinel of Duboštica appears to be characteristic of the podiform deposits associated with the Alpine gabbro-peridotite complex (Sunarić \& Olujić 1968, Pamić 1970, 1974).

\section{EXPERIMENTAL}

The minerals investigated were identified by powder X-ray diffraction, on a vertical Philips goniometer using a graphite monochromator. Indexed powder patterns of gaspéite, retgersite and nickelhexahydrite were used to calculate unit-cell dimensions.

Four sets of ICP-AES (inductively coupled plasma - atomic emission spectrometry) analyses were done on carefully selected crystals of gaspéite. The analyses were performed on a ARL ICP-35000C atomic emis-
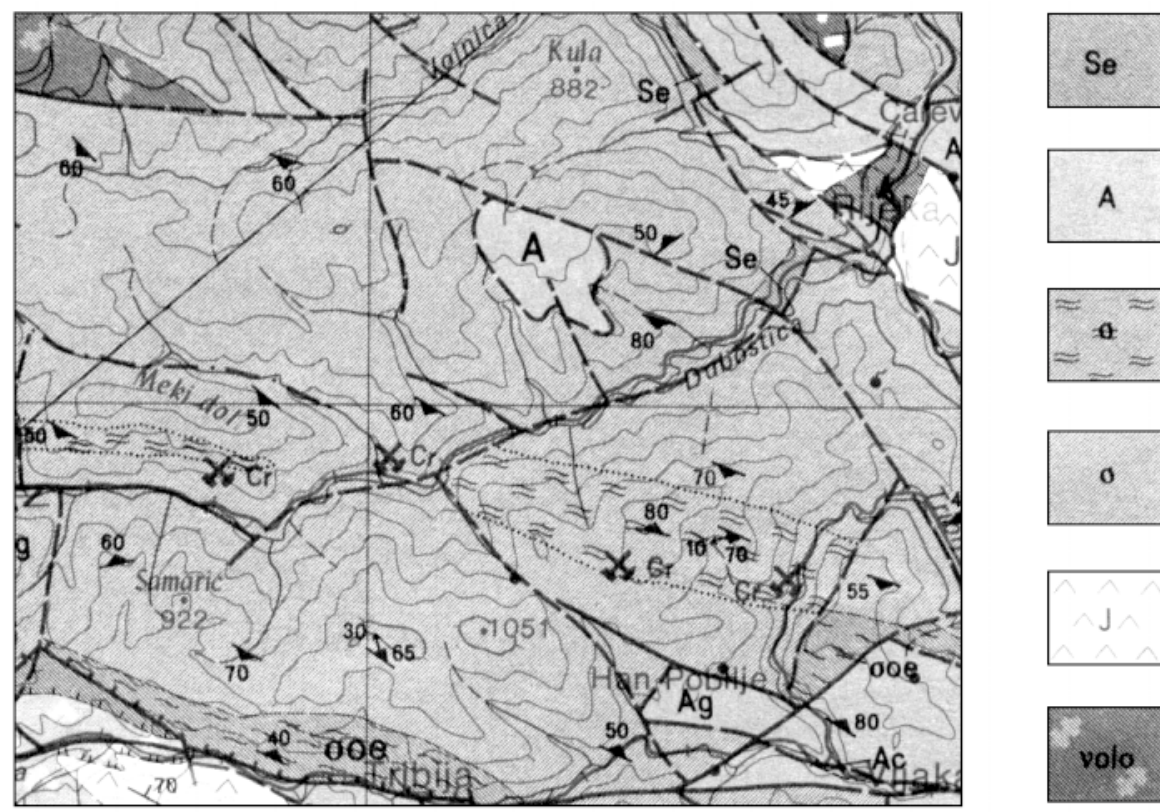

SERPENTINITE

AMPHIBOLITE

PERIDOTITE

LHERZOLITE

JURASSIC

SEDIMENTS

FIG. 1. Geological setting of peridotitic rocks in Duboštica area. Se: serpentinite, A: amphibolites, o: altered peridotite and lherzolite, J: Jurassi sediments, volo: troctolite. 
sion spectrometer with the Ar-plasma excitation mode. The plasma flow was a standard $14 \mathrm{dm}^{3} \mathrm{~min}^{-1}$ of argon, the input power being set at $1200 \mathrm{~W}$.

The $\mathrm{CO}_{2}$ content was determined by thermogravimetric analysis, combined with an infrared powder spectrum recorded on a Perkin-Elmer 397 IR spectrometer. The potassium bromide pellet technique was applied, with the KBr to sample ratio 100:1. Densities of the minerals were not measured because of the small quantity of available material and the intimate intergrowth of the minerals. Thin sections of gaspéite were used for investigations with the polarizing microscope (Zeiss Axiolab Standard 25).

\section{Physical Properties of Gaspéite}

Gaspéite crystals are simple, plate-like flattened $\{104\}$ rhombohedra, with a vitreous to pearly luster. The crystals are pearly, up to $5 \mathrm{~mm}$ in size. Gaspéite is translucent, with a light green color and yellow-green streak. In thin sections, it is light green, without pleochroism or "pseudoabsorption" effects. It shows a white fluorescence under short- and long-wave ultraviolet light.

On the Mohs hardness scale, gaspéite has a value of $4 \frac{1}{2}$ to 5 . It is brittle, with a good cleavage on $\{101\}$, and has an uneven fracture.

The calculated density is $3.91 \mathrm{~g} / \mathrm{cm}^{3}$. This is greater than the measured density of gaspéite from the type locality (3.71 g/ $\mathrm{cm}^{3}$ : Kohls \& Rodda 1966) and reflects the lower $\mathrm{Mg}$ and higher $\mathrm{Ni}$ content of the mineral from Duboštica.

\section{Chemical Composition of Gaspéite}

Several crystals of gaspéite, carefully separated with a binocular microscope, were dissolved in $\mathrm{HCl}$ (Merck p.a.) and analyzed for $\mathrm{Ni}, \mathrm{Fe}, \mathrm{Ca}, \mathrm{Mg}, \mathrm{Mn}$ and $\mathrm{Zn}$, since these elements form the rhombohedral group of carbonate minerals. The concentration of zinc is below the detection limit ( $>1 \mathrm{ppm}$ of $\mathrm{Zn}$ in the analyzed solution).

TABLE 1. CHEMICAL COMPOSITION OF GASPÉITE FROM DUBOSTTICA, BOSNIA AND HERZEGOVINA

\begin{tabular}{lccllll}
\hline & Duboštica & Gaspé & & Duboštica & Gaspé \\
& & & & & & \\
$\mathrm{NiO} w \mathrm{wt} \%$ & 49.63 & 35.0 & $\mathrm{Ni}^{2+}$ apfu & 0.730 & 0.49 \\
$\mathrm{MgO}$ & 0.17 & 17.3 & $\mathrm{Mg}$ & 0.005 & 0.45 \\
$\mathrm{CaO}$ & 0.45 & - & $\mathrm{Ca}$ & 0.009 & - \\
$\mathrm{FeO}$ & 6.36 & 5.7 & $\mathrm{Fe}^{2+}$ & 0.097 & 0.08 \\
$\mathrm{MnO}$ & 0.006 & - & & & \\
$\mathrm{CO}_{2}$ & 43.25 & $42.0^{*}$ & $\mathrm{C}^{4+}$ & & 1.080 & 0.99 \\
& & & & & & \\
Total & 99.87 & 100.00 & & & & \\
\hline
\end{tabular}

* The $\mathrm{CO}_{2}$ content was determined from the infrared spectrum of gaspéite, and from the loss on ignition (LOI) recorded on the thermogravimetric curve. IInformation taken from Kohls \& Rodda (1966).
The average of four analyses yielded the empirical formula (based on three atoms of oxygen) $\left(\mathrm{Ni}_{0.73} \mathrm{Fe}_{0.10}\right.$ $\left.\mathrm{Ca}_{0.01}\right)_{\Sigma 0.84} \mathrm{C}_{1.08} \mathrm{O}_{3.00}$ (Table 1). Thus, the gaspéite from Duboštica is a solid solution of $86.9 \mathrm{~mol} \% \mathrm{NiCO}_{3}, 11.9$ $\mathrm{mol} \% \mathrm{FeCO}_{3}$ and $1.2 \mathrm{~mol} \% \mathrm{CaCO}_{3}$, and its composition lies between the gaspéite from Gaspé (Kohls \& Rodda 1966) and that from Transvaal (Mariano et al. 1969).

\section{Associated Minerals}

Two other Ni-rich minerals occur with, and in some cases are intimately mixed with, the crystals of gaspéite: nickelhexahydrite [bluish green, tetragonal; $a$ 6.787(5), $c$ 18.27(2) $\mathrm{A}, V$ 842(1) $\AA^{3}$ ] and retgersite [monoclinic; $a$ 9.925(7), b 7.232(7), c 24.16(2) $\AA, \beta$ 98.55(7) ${ }^{\circ}, V$ $\left.1715(2) \AA^{3}\right]$. The X-ray powder-diffraction data of these three minerals compare favorably with the data published elsewhere (Kohls \& Rodda 1966; PDF 8-470, 33-955 (PCPDFWIN 1996, Nawaz 1973). The only other mineral found in the veins is yellow opal.

$$
\begin{aligned}
& \text { Eh-pH Stability Diagram } \\
& \text { FOR THE System Ni-O-H-S-C }
\end{aligned}
$$

Figure 2 shows the Eh-pH diagram for the system $\mathrm{Ni}-\mathrm{O}-\mathrm{H}-\mathrm{S}-\mathrm{C}$, constructed using the HSC software (version 4.0). The thermodynamic data for important nickel species are given in Table 2. All values of free energy were taken from Wagman et al. (1982), except for $\mathrm{HNiO}_{2}^{-}$(Garrels \& Christ 1965) and for the hydrated nickel sulfate minerals retgersite and morenosite (Robie et al. 1978). The more recently proposed value of $-628.359 \pm 1.24 \mathrm{~kJ} / \mathrm{mol}$ for nickel carbonate (Tareen et al. 1991) is considerably more positive, but has not been used as it was derived from hydrothermal decomposition (decarbonation) curves and not by direct calorimetric measurements.

In the diagram, a rather narrow field of predominance of $\mathrm{Ni}(\mathrm{OH})_{2}$ (in the $\mathrm{pH}$ range 9-11) separates the

TABLE 2. THERMODYNAMIC DATA FOR THE SYSTEM Ni-O-H-S-C

\begin{tabular}{llr}
\hline Species (state) & Mineral species & $\Delta \mathrm{G}_{\mathrm{f}}^{0}$ \\
\hline $\mathrm{Ni}^{2+}(\mathrm{aq})$ & & -45.62 \\
$\mathrm{NiO}$ & Bunsenite & -211.81 \\
$\mathrm{Ni}(\mathrm{OH})_{2}$ & & -447.39 \\
$\mathrm{NiS}$ & Millerite & -79.53 \\
$\mathrm{NiSO}$ & & -760.03 \\
$\mathrm{NiSO}_{4} \cdot 6 \mathrm{H}_{2} \mathrm{O}$ & Retgersite & -222.45 \\
$\mathrm{NiSO}_{4} \cdot 7 \mathrm{H}_{2} \mathrm{O}$ & Morenosite & -246.17 \\
$\mathrm{NiCO}_{3}$ & Gaspéite & -612.78 \\
$\mathrm{NiOH}^{+}(\mathrm{aq})$ & & -227.71 \\
$\mathrm{HNiO}_{2}^{-}$(aq) & & -349.36 \\
\hline
\end{tabular}

$\Delta \mathrm{G}_{\mathrm{f}}^{0}$ is expressed in (kJ/gfw). 


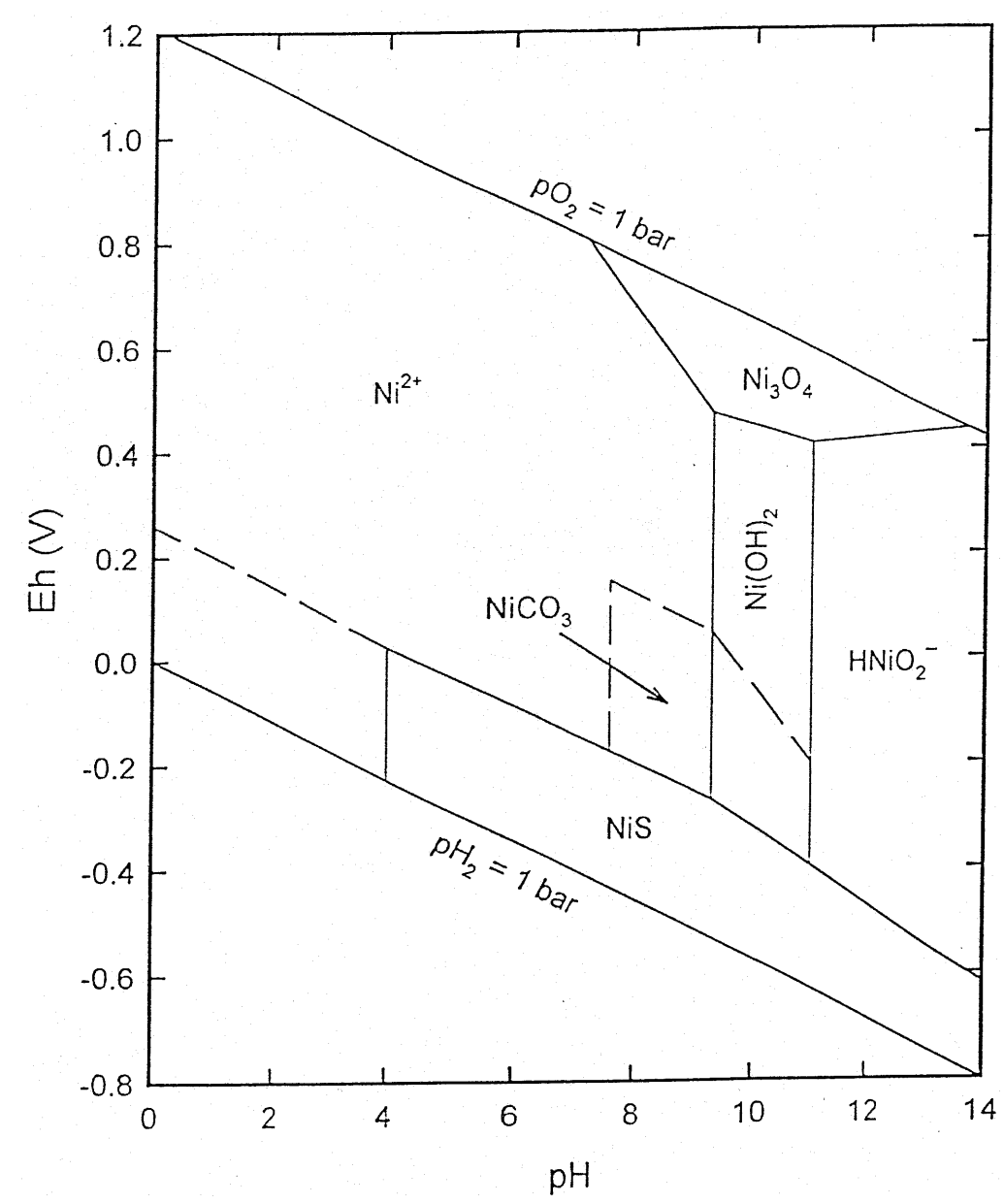

FIG. 2. Eh-pH diagram for part of the system Ni-O-H-S-C. Assumed activities for dissolved species are: $\mathrm{Ni}=10^{-4}, \mathrm{~S}=10^{-3}, \mathrm{C}=10^{-3}$ (all in mol/L), at $298 \mathrm{~K}$ and 1 bar.

large $\mathrm{Ni}^{2+}$ area from that of $\mathrm{HNiO}^{2-}$. This diagram shows an enhanced mobility of nickel in sulfur-poor systems under approximately neutral to acidic conditions. The significance of sulfur is shown by the large field of $\gamma$ NiS (millerite) occurring below the sulfate-sulfide boundary. In the system described, both $\mathrm{NiOH}^{+}$and $\mathrm{NiCO}_{3}$ are metastable with respect to $\mathrm{Ni}^{2+}$ and $\mathrm{Ni}(\mathrm{OH})_{2}$. The $\mathrm{NiCO}_{3}$ field is delineated with a dashed line to show the likely range of formation of gaspéite. Nickel sulfate species are not in thermodynamic equilibrium with the other ionic forms of nickel, and thus the Eh-pH diagram shows no field of predominance for sulfate.

\section{DisCUSSION}

The association of these rare nickel minerals is a result of circulation of hydrothermal solutions through the peridotite. As a result of alteration processes, $\mathrm{Ni}$ was probably leached from the primary minerals, most likely olivine. There are relics of an unidentified pyroxene in the altered peridotite. It occurs together with altered (serpentinized) olivine. According to Pamic (1970), the pyroxene is probably enstatite.

The hydrated nickel sulfate minerals, nickelhexahydrite $\left(\mathrm{NiSO}_{4} \bullet 6 \mathrm{H}_{2} \mathrm{O}\right.$, green, monoclinic), retgersite $\left(\mathrm{NiSO}_{4} \bullet 6 \mathrm{H}_{2} \mathrm{O}\right.$, blue, tetragonal), and morenosite $\left(\mathrm{NiSO}_{4} \bullet 7 \mathrm{H}_{2} \mathrm{O}\right)$ are not in equilibrium with gaspéite $\left(\mathrm{NiCO}_{3}\right)$ or millerite $(\gamma-\mathrm{NiS})$. The hydrated sulfates have probably formed by secondary hydration reactions at lower temperatures, perhaps within periods of marked increase in concentration of the solution due to evaporation or other causes of water depletion. The hydrated nickel sulfate minerals, as investigated also with various synthetic compounds (Frondel \& Palache 1949, and 
references therein), undergo rapid changes within a rather narrow range of temperatures pertaining to mild hydrothermal conditions. Thus, morenosite dehydrates rapidly to retgersite in dry air under $304.65 \mathrm{~K}$, whereas nickelhexahydrite forms above $326.45 \mathrm{~K}$. A dihydrate $\left(\mathrm{NiSO}_{4} \cdot 2 \mathrm{H}_{2} \mathrm{O}\right)$ apparently forms above $391 \mathrm{~K}$.

A hot spring system, at higher temperatures and different concentrations of nickel and sulfur, would have resulted in a different Eh-pH diagram. Unlike cobalt, nickel does not form thermodynamically stable carbonate species in aqueous solution. The $\mathrm{NiCO}_{3}$ species is metastable and under certain kinetically favored conditions, including high activities of $\mathrm{Ni}$, forms solid-solution minerals of the gaspéite type. Together with elements like chromium and cobalt, nickel is strongly enriched in ultramafic rocks, forming complex arsenide and sulfide minerals (pentlandite, nickeline, gersdorffite). However, partly owing to interactions and complexing with organic matter, nickel is mobilized in the oxidized zones and aqueous hydrothermal phases of such host rocks. Because of this, nickel minerals of the oxysalt type are rare, even though $\mathrm{Ni}$ concentrations in the lithosphere are comparatively high.

Apart from $\mathrm{pH}$ and the activity of species, the redox potential is an important parameter, as it has a strong influence on the mobility and complexation of metal cations in hydrothermal systems (Seward \& Barnes 1997). The structurally bound iron in gaspéite implies that the various mineral phases were formed under different chemical conditions with respect to the redox potential. Thus the paragenesis needs to be understood in terms of near-surface alteration. The source of carbon dioxide is either ambient air or hydrothermal solutions enriched in $\mathrm{CO}_{2}$.

The transition elements, including nickel, have a marked preference for certain silicate, oxide and sulfide phases, which makes them important geochemical tracers for specific magmatic processes. The partitioning of nickel between olivine and sulfide liquid has been used in the assessment of crystallization models for the origin of layered intrusions and associated sulfide deposits (Barnes \& Naldrett 1985, Fleet \& MacRae 1987). Information on the pattern of partitioning of nickel between Ni-rich minerals and associated hydrothermal fluids will also help in the understanding of the oxygen fugacity of melts from which the hosting ultramafic complex crystallized.

The described association of nickel minerals from Duboštica has most likely been caused by a series of kinetically controlled transitory equilibria. The presence of redox-sensitive elements $(\mathrm{Fe})$ in gaspéite, and the chemical data argue against the simultaneous formation of the minerals in the assemblage. The concomitant occurrence of mineral phases representing non-equilibrium conditions, as in the case of the association described from Duboštica, is most probably the result of a series of transitory equilibria sequentially attained in the near-surface environment of the altered ultrama- fic suites. Mineral associations containing both carbonate and soluble sulfate minerals are rare, since the formation of free $\mathrm{H}_{2} \mathrm{SO}_{4}$ normally results in a dissolution of the carbonate phases. It is even less common to find two sulfate polymorphs occurring together in the same paragenesis.

\section{ACKNOWLEDGEMENTS}

This manuscript benefitted from the constructive comments and helpful insights of Robert F. Martin and two anonymous reviewers. This study was partially supported by grants from the ministries of science of Croatia and Bosnia and Herzegovina.

\section{REFERENCES}

BARnES, S.J. \& NALDRETT, A.J. (1985): Geochemistry of the J-M (Howland) Reef of the Stillwater complex, Minneapolis Adit area. I. Sulfide chemistry and sulfideolivine equilibrium. Econ. Geol. 50, 627-645.

Fleet, M.E. \& MacRae, N.D. (1987): Partitioning of Ni between olivine and sulfide: the effect of temperature, $f_{\mathrm{O} 2}$ and $f_{\mathrm{S} 2}$. Contrib. Mineral. Petrol. 95, 336-342.

Frondel, C. \& Palache, C. (1949): Retgersite, $\mathrm{NiSO}_{4} \bullet 6 \mathrm{H}_{2} \mathrm{O}$, a new mineral. Am. Mineral. 34, 188- 194.

GARrels, R.M. \& Christ, C.L. (1965): Solutions, Minerals and Equilibria. Harper and Row, New York, N.Y.

HSC - Chemistry for Windows (Chemical Reaction and Equilibrium Software) (1999): Users guide, version 4.0, Outokumpu Research Oy, Pori, Finland.

Kohls, D.W. \& RoddA, J.L. (1966): Gaspéite, $(\mathrm{Ni}, \mathrm{Mg}, \mathrm{Fe})\left(\mathrm{CO}_{3}\right)$, a new carbonate from the Gaspé Peninsula, Quebec. Am. Mineral. 51, 677-684.

Mariano, A.N., PojaseK, W.J. \& Bender, S.L. (1969): Nickelcarbonate from northeast Transvaal. Can. Mineral. 10, 140 (abstr.).

NAwAZ, R. (1973): Nickel-hexahydrite from Tasmania, Australia. Mineral. Mag. 39, 246-247.

PAMIć, J. (1970): Basic data on the petrology of the chromite mine Duboštica in the Dinaridic zone of Yugoslavia. Geološki Glasnik (Sarajevo) 14, 135-148.

(1974): Alpine-type gabbros within the Krivaja Konjuh ultramafic massif in the ophiolite zone of the Dinarides, Yugoslavia. Tschermaks Mineral. Petrogr. Mitt. 21, 261-279.

PCPDFWIN version 1.20 (1996): International Center for Diffraction Data, Newton Square, Pennsylvania.

REEDER, R.J., ed. (1983): Carbonates: Mineralogy and Chemistry. Rev. Mineral. 11. 
Robie, R.A., Hemingway, B.S. \& Fisher, J.R. (1978): Thermodynamic properties of minerals and related substances at $298.15 \mathrm{~K}$ and 1 bar pressure and at higher temperatures. U.S. Geol. Surv., Bull. 1452.

SewARD, T.M. \& BARNES, H.L. (1997): Metal transport by hydrothermal ore fluids. In Geochemistry of Hydrothermal Ore Deposits ( $3^{\text {rd }}$ edition, H.L. Barnes, ed.). John Wiley \& Sons, New York, N.Y. (435-486).

SunARIĆ, O. \& OLuJIĆ, J. (1968): Basic geological characteristics of the Duboštica chromite deposit. Geološki Glasnik (Sarajevo) 12, 261-271.

TAReEn, J.A.K., FAzeli, A.R., Basavalingu, B. \& Bhandage, G.T. (1991): Hydrothermal decomposition curves and ther- modynamic data for spherocobaltite $\left(\mathrm{CoCO}_{3}\right)$ and gaspéite $\left(\mathrm{NiCO}_{3}\right)$. Eur. J. Mineral. 3, 501-505.

Wagman, D.D., Evans, W.H., Parker, V.B., Schumm, R.H., Harlow, I., Bailey, S.M., Churney, K.L. \& Butall, R.L. (1982): The NBS tables of chemical thermodynamic properties. Selected values for inorganic and $\mathrm{C} 1$ and $\mathrm{C} 2$ organic substances in SI units. J. Phys. Chem. Ref. Data 11, Suppl. 2.

Received September 20, 1999, revised manuscript accepted September 22, 2000. 